\title{
Penguatan Iptek dan kearifan lokal dalam pengelolaan perikanan di Desa Pangkalan Jambi Kecamatan Bukit Batu Kabupaten Bengkalis
}

\author{
Dadang Mashur*, Ridwan Manda Putra, Herman, Mayarni, Mimin Sundari Nasution, Eka Hariyani, \\ Musadad, dan Risky Arya Putri
}

Universitas Riau

* dadangmashur180685@gmail.com

\begin{abstract}
Abstrak. Daerah pesisir memiliki banyak potensi sumber daya yang pemanfaatannya belum optimal. Salah satu potensi yang harus dikembangkan adalah potensi sumber daya manusia, dengan kemampuan dan kreativitas, manusia dapat menciptakan dan mengembangkan segala hal yang awalnya tidak diperhatikan dan memiliki nilai jual rendah menjadi sesuatu yang memiliki nilai ekonomis yang tinggi. Penguatan Iptek ini bertujuan untuk memotivasi masyarakat desa terutama nelayan untuk mengembangkan kreativitas sehingga bisa meningkatkan pendapatan dan kesejahteraan masyarakat nelayan. Kegiatan penguatan iptek ini dilakukan di Desa Pangkalan Jambi dengan dua model yaitu penerapan dengan model Center for Environment and Society yaitu memanfaatkan penggunaan secara produktif modal sosial dan pengelolaan sumber daya perikanan dengan ramah lingkungan. Penerapan kedua yakni dengan model Entrepreneuership Capacity Building (ECB) terkait dengan kemampuan masyarakat berwirausaha. Kegiatan penguatan IPTEK dan kearifan lokal berupa pembinaan terhadap masyarakat nelayan dalam pengelolaan hasil perikanan seperti keripik, nugget, bakso, minyak ikan, sebagai obat-obatan dan jelly ikan sebagai kosmetik. Kemudian pembinaan kelembagaan serta pendampingan untuk pemasaran. Selama ini nelayan hanya mampu menjual hasil tangkapannya secara langsung tanpa adanya pengolahan berbasis teknologi. Setelah dilakukan pengabdian, ada tiga program yang dilakukan diantaranya pembentukan skill individu dalam pengolahan ikan, pembentukan kelompok serta bantuan manajemen pemasaran.
\end{abstract}

Kata kunci: kelembagaan; pengelolaan; penguatan IPTEK; perikanan

\begin{abstract}
The coastal area has many potential resources whose utilization is not optimal. One potential that must be developed is the potential of human resources, with ability and creativity, humans can create and develop everything that is initially not considered and has a low selling value into something that has high economic value. The strengthening of science and technology aims to motivate rural communities, especially fishermen, to develop creativity so that they can increase the income and welfare of fishing communities. The science and technology strengthening activity was carried out in Pangkalan Jambi Village with two models, namely the application of the Center for Environment and Society Model, namely utilizing the productive use of social capital and environmentally friendly management of fisheries resources. The second application is the Entrepreneurship Capacity Building (ECB) model related to the ability of the entrepreneurial community. Science and technology strengthening activities and local wisdom in the form of fostering fishing communities in the management of fishery products such as chips, nuggets, meatballs, oil, as medicines and fish jelly as cosmetics. Then institutional development and assistance for marketing. So far, fishermen are only able to sell their catches directly without technology-based processing. After the dedication, there were three programs carried out including the formation of individual skills in fish processing, group formation, and marketing management assistance.
\end{abstract}

Keywords: institutional; management; strengthening of science and technology; fishery

To cite this article: Mashur, D., R. M. Putra, Herman, Mayarni, M. S. Nasution, E. Hariyani, Musadad, \& R. A. Putri. 2019. Penguatan Iptek dan kearifan lokal dalam pengelolaan perikanan di Desa Pangkalan Jambi Kecamatan Bukit Batu Kabupaten Bengkalis. Unri Conference Series: Community Engagement 1: 290-296 https://doi.org/10.31258/unricsce.1.290-296

(C) 2019 Authors

Peer-review under responsibility of the organizing committee of Seminar Nasional Pemberdayaan Masyarakat 2019 


\section{PENDAHULUAN}

Melalui Undang-Undang Otonomi Daerah, masing-masing daerah memiliki kewenangan terhadap pengelolaan wilayah pesisir. Wilayah pesisir memiliki peran yang sangat penting khususnya dalam pengembangan sektor perikanan mengingat Indonesia yang merupakan negara kepulauan (Kamal, 2013). Pengembangan sektor perikanan menjadi perhatian utama bagi pemerintah. Hal tersebut dibuktikan dengan berbagai kebijakan pemerintah yang bersifat melindungi sumberdaya ikan dan lingkungan. Selain itu, berbagai cara juga dilakukan pemerintah untuk mensejahterakan masyarakat terutama nelayan dengan digulirkannya kebijakan fiskal maupun non fiskal. Selain pada sektor perikanan, wilayah pesisir memiliki banyak potensi yang pemanfaatannya belum optimal. Peran serta sumber daya manusia sangat berpengaruh terhadap pengembangan potensi wilayah pesisir terutama di sektor perikanan.

Kecamatan Bukit Batu menjadi salah satu kecamatan yang patut diperhitungkan karena kekayaan alamnya. Kecamatan Bukit Batu merupakan salah satu dari 13 kecamatan yang terletak di Kabupaten Bengkalis dengan luas wilayah $1.128 \mathrm{~km}^{2}$. Dalam hal ini, desa yang memiliki potensi dalam bidang perikanan adalah Desa Pangkalan Jambi. Sejak tahun 2004 desa Pangkalan Jambi Kecamatan Bukit Batu Kabupaten Bengkalis telah mengalami pengikisan daratan akibat abrasi pantai hingga sejauh 83 meter. Tercatat pada saat sebelum terjadi abrasi, terdapat puluhan kepala keluarga yang bermukim di pinggir pantai. Kerusakan makin diperparah dengan kondisi geografis yang menempatkan Desa Pangkalan Jambi menjadi sasaran dari arus selat dan sungai yang disebut sebagai arus tiga penjuru (arus Selat Lalang, arus Sungai Siak Sri Indrapura, serta arus dari Sungai Siak Kecil). Arus dari Selat Lalang yang lebih besar mengarah ke Desa Pangkalan Jambi sehingga Desa ini menjadi salah satu Desa yang paling berdampak besar terhadap kerusakan ekosistem hutan mangrove akibat abrasi pantai. Selain disebabkan faktor geografis, kerusakan ekosistem mangrove di daerah ini juga diakibatkan oleh perilaku masyarakat yang menebang kayu mangrove tanpa menanam kembali untuk berbagai keperluan seperti untuk keperluan kayu bakar, kayu cerocok untuk bahan konstruksi bangunan dan rumah sehingga kebutuhan akan kayu bakau menjadi meningkat.

Kondisi pasca abrasi tentu berdampak pada kehidupan ikan disekitar laut. Hutan mangrove selama ini dikenal sebagai salah satu rantai makanan dimana mangrove berperan sebagai produsen. Tanaman mangrove banyak disukai ikan-ikan kecil dan juga kepiting dan tidak sedikit jenis ikan yang menggantungkan hidup dengan memakan daun mangrove. Oleh karena itu nelayan meyakini bahwa dampak abrasi dan kerusakan mangrove yang selama ini terjadi berpengaruh terhadap jumlah tangkapan ikan mereka. Nelayan mengeluhkan bahwa hasil tangkap ikan yang memiliki daya jual yang tinggi seperti ikan terubuk mengalami penurunan, bahkan telur ikan terubuk sangat sulit untuk didapatkan. Sebaliknya hasil tangkap ikan lomek yang memiliki harga jual yang rendah selalu mengalami kenaikan. Ikan lomek adalah jenis ikan dengan kadar air yang tinggi sehingga mudah sekali mengalami pembusukan. Nelayan mengeluhkan bahwa jumlah ikan lomek yang didapat tidak sebanding dengan daya beli masyarakat. Mempertimbangkan hal tersebut, para nelayan merasa butuh alternatif atau mata pencaharian tambahan dengan mencoba menggali potensi perikanan serta mengelolanya.

\section{PERMASALAHAN}

Menurut Tuwo (2011) kekurangberdayaan masyarakat pesisir antara lain disebabkan oleh keterbatasan mereka dalam penguasaan ilmu, teknologi, modal dan kelembagaan usaha. Selain itu, menurut Tuwo (2011) paling tidak ada lima pendekatan pemberdayaan masyarakat pesisir yang baru saja diimplementasikan. Kelima pendekatan ini dilaksanakan dengan memperhatikan secara sungguh-sungguh aspirasi, keinginan, kebutuhan, pendapatan, dan potensi sumberdaya yang dimiliki masyarakat. Komponen dari pendekatan pemberdayaan masyarakat pesisir dapat dijelaskan sebagai berikut:

1. Pengembangan mata pencaharian alternatif

Pengembangan mata pencaharian alternatif dilaksanakan dengan pertimbangan bahwa sumber daya pesisir secara umum dan perikanan tangkap secara khusus telah banyak mengalami tekanan dan degradasi. Secara estimasi nasional, jumlah nelayan yang cukup banyak tidak sebanding dengan jumlah ikan yang diperbolehkan untuk ditangkap sehingga diperkirakan lambat laun kehidupan nelayan akan sulit untuk sejahtera. Oleh karena itu butuh pengembangan mata pencaharian alternatif melalui tindakan pembinaan. 
2. Akses terhadap modal

Strategi ini sangat penting karena pada dasarnya saat ini masyarakat pesisir, khususnya nelayan dan pembudidaya ikan sangat sulit untuk memperoleh modal. Sifat bisnis perikanan yang musiman, ketidakpastian serta resiko tinggi sering menjadi alasan keengganan bank menyediakan modal bagi bisnis ini (Tuwo,2011). Sifat bisnis perikanan seperti ini yang disertai dengan status nelayan yang umumnya rendah dan tidak mampu secara ekonomi membuat mereka sulit untuk memenuhi syaratsyarat perbankan yang selayaknya diberlakukan seperti perlu adanya collateral, insurance dan equity.

3. Akses Terhadap Teknologi

Upaya yang dilakukan sebaiknya meningkatkan pendapatan dilakukan melalui perbaikan teknologi, mulai dari teknologi produksi hingga pasca produksi dan pemasaran. Upaya-upaya peningkatan akses masyarakat terhadap teknologi belum banyak dilakukan. Hal ini karena adanya kesulitan untuk mengindentifikasi jenis dan tipe teknologi yang dibutuhkan masyarakat. Seringkali, justru masyarakatlah yang lebih maju dalam mencari dan mengadopsi teknologi yang diinginkan. Sehingga kadang-kadang pemerintah tertinggal. Dengan kata lain, dalam hal teknologi masyarakat lebih maju dari pemerintah (Tuwo, 2011).

4. Akses terhadap pasar

Membuka akses pasar adalah cara untuk mengembangkan usaha karena bila tidak ada pasar maka usaha sangat terhambat perkembangannya. Untuk mengembangkan pasar bagi produk-produk yang dihasilkan masyarakat pesisir maka upaya yang dilakukan adalah mendekatkan masyarakat dengan perusahaanperusahaan besar yang juga adalah eksportir komoditas perikanan. Untuk itu maka kontrak penjualan produk antara masyarakat nelayan dengan perusahaan ini dilaksanakan (Tuwo, 2011).

5. Pengembangan aksi kolektif

Pemberdayaan melalui pengembangan aksi kolektif sama artinya dengan pengembangan koperasi atau kelompok usaha bersama (Tuwo, 2011). Hanya di sini istilah yang digunakan adalah aksi kolektif yaitu untuk membuka kesempatan kepada masyarakat membentuk kelompok-kelompok yang diinginkannya yang tidak semata-mata koperasi atau kelompok usaha bersama.

Berdasarkan hasil pengamatan dilapangan ada beberapa hal krusial yang dialami nelayan diantaranya kurangnya pengetahuan terhadap pengembangan pencaharian alternatif, kurangnya modal serta kurangnya pemahaman dan akses terhadap teknologi. Kelompok nelayan memiliki kemampuan namun tidak didukung dengan adanya pemberdayaan dalam berbagai bidang. Saat ini perekonomian masyarakat nelayan di Desa Pangkalan Jambi saat ini mengalami penurunan, hal ini di sebabkan oleh hasil tangkapan ikan yang terus menurun, terutama ikan yang mempunyai nilai jual yang cukup tinggi seperti ikan terubuk, ikan pias, ikan tenggiri dan ikan biang. Sebaliknya hasil tangkapan yang paling banyak jumlahnya yakni jenis ikan lomek, tetapi jenis ikan ini memiliki nilai jual yang cukup rendah dipasaran.

Rendahnya pendapatan nelayan menyebabkan nelayan hidup dalam kemiskinan. Ketidaktahuan terhadap potensi serta minimnya pengetahuan terhadap penggunaan teknologi membuat keadaan nelayan semakin memburuk (Surya, 2008). Nelayan selalu mengalami kerugian akibat harga jual ikan lomek yang begitu rendah dan kurangnya minat pembeli. Selain itu, nelayan juga memiliki pengetahuan yang minim untuk melakukan pengolahan ikan lomek menjadi makanan olahan lainnya seperti nugget, bakso maupun untuk mengolah ikan lomek menjadi obat-obatan seperti minyak ikan dan jelly ikan sebagai kosmetik. Nelayan hanya mampu mengolah hasil tangkap ikan secara tradisional dan pengemasan yang sederhana sehingga kurang menarik minat pembeli.

\section{METODE}

Penerapan pembinaan dilakukan dengan model Central for Environmental and Society dan Entrepreneurship Capacity Building (ECB). Pelaksanaan pembinaan ini dilakukan dengan teknik ceramah, diskusi dan praktek langsung pada desa pembinaan yakni Desa Pangkalan Jambi. Dalam proses ceramah, diskusi dan praktek dilakukan dengan pemberian tugas juga, baik yang dikerjakan dilokasi maupun dibawa pulang untuk di uji coba kepada masyarakat yang dibina. Kemudian diberikan pembinaan dan akan diketahui capaian pembinaan yang dilakukan.

1. Penerapan dengan model Center for Environmental and Society

Model ini didefinisikan sebagai suatu usaha berkelanjutan yang merupkakan suatu cara memanfaatkan barang-barang alamiah dan jasa yang tidak merusak lingkungan dan memanfaatkan pengetahuan serta 
keterampilan para nelayan yang pada akhirnya meningkatkan kemandirian dan kemampuan mereka. Model ini juga dapat diterapkan yaitu dengan memanfaatkan penggunaan secara produktif "social capital" atau model sosial yaitu kemampuan orang untuk bekerjasama dalam memecahkan permasalahan-permasalahan nelayan dalam pengelolaan hasil tangkapan.

2. Penerapan dengan model Entrepreneuership Capacity Buiding (ECB)

Model ini terkait dengan kemampuan berwirausaha dari nelayan, dengan model diharapkan (1) memberikan wawasan, sikap dan keterampilan usaha, (2) memberikan peluang, (3) memfasilitasi dan (4) memonitor dan mengevaluasi.

Langkah penerapan model ini secara real di lapangan oleh tim pengusul pembinaan masyarakat nelayan di daerah pesisir, diantaranya akan diterapkan sebagai berikut:

1. Sosialisasi kegiatan pemberdayaan masyarakat dan administrasi yang akan dilakukan dalam rangka mencapai tujuan pembinaan desa.

2. Pelatihan dan pembinaan bagi masyarakat nelayan di bidang industri rumah tangga

3. dalam hal pengelolaan hasil tangkap perikanan.

4. Pembinaan bidang kuliner dengan program kewirausahaan pengembangan produk kuliner baik yang siap saji maupun kemasan, tentunya masyarakat nelayan Desa Pangkalan Jambi harus memiliki keterampilan mengolah komoditi ikan laut sebagai industri rumah tangga yang memiliki prospek ekonomis untuk dipasarkan.

5. Peningkatan kualitas sumber daya manusia masyarakat nelayan Desa Pangkalan Jambi antara lain melalui pembentukan kelembagaan dan penyuluhan secara kontinu dan intensif terhadap seluruh nelayan di daerah pesisir dan evaluasi/ pembinaan terhadap usaha nelayan pesisir.

6. Pendampingan pemasaran (kemasan).

\section{Teknik Penyelesaian Masalah}

1. Mengidentifikasi dan memahami tentang kondisi-kondisi yang ada (Das Sein). Berupaya mengidentifikasi dan memahami tentang kondisi-kondisi yang ada pada lokasi pengabdian tersebut secara keseluruhan. Aturan dan pedoman komponen-komponen dan faktor-faktor yang sesuai dengan model, serta menganalisa permasalahan masyarakat desa.

2. Mengidentifikasi tentang kondisi yang diinginkan (Das Sollen)

Berisi berbagai faktor yang mungkin perlu perubahan dan perkembangannya dengan catatan perubahan yang diinginkan itu disesuaikan dengan kebutuhan masyarakat dan kondisi yang diinginkan harus keadaan yang mungkin dapat dicapai.

\section{PEMBAHASAN}

Pemberdayaan dapat diartikan sebagai upaya untuk memenuhi kebutuhan yang diinginkan oleh individu, kelompok dan masyarakat luas agar mereka memiliki kemampuan untuk melakukan pilihan dan mengontrol lingkungannya agar dapat memenuhi keinginan-keinginanya, termasuk aksesbilitasnya terhadap sumberdaya yang terkait dengan pekerjaanya, aktivitas sosialnya (Totok dan Poerwoko, 2012).

Pada dasarnya, pemberdayaan masyarakat nelayan bertujuan untuk mencapai kesejahteraan sosia-budaya dan hal ini menjadi dasar membangun kawasan pesisir. Untuk mencapai tujuan ini diperlukan dukungan kualitas sumberdaya manusia dan fungsi kelembagaan sosial ekonomi yang optimal dalam kehidupan warga. Oleh karena itu, diperlukan perencanaan dan tujuan yang terukur, yang pencapaianya dilakukan secara bertahap. Dengan memperhatikan kemampuan sumberdaya pembangunan yang dimiliki oleh masyarakat pesisir (Kusnadi, 2007).

Perkembangan ilmu pengetahuan selalu diikuti oleh perkembangan teknologi. Teknologi adalah suatu studi sistematik akan teknik-teknik untuk membuat dan mengerjakan berbagai benda, sedang ilmu adalah usaha sistematik untuk memahami dan menfsirkan dunia. (Buchanan, 2006). Desa Pangkalan Jambi merupakan salah satu desa yang berpotensi dalam bidang perikanan di Kecamatan Bukit Batu Kabupaten Bengkalis, hal ini dibuktikan dengan mayoritas mata pencaharian masyarakat adalah sebagai nelayan. Terdapat satu hal yang membedakan desa Pangkalan Jambi dengan desa lainnya yakni komitmen yang dimiliki oleh masyarakat desa dalam menjaga lingkungan serta mengelola hasil tangkap ikan. Sejak tahun 2013, berbagai kendala dialami oleh masyarakat terutama nelayan dalam proses pengolahan hasil tangkap ikan. Selain sulitnya memasarkan 
ikan dengan cara konvensional, jumlah tangkapan ikan yang memiliki nilai ekonomis yang tinggi juga semakin menurun.

Ikan terubuk ataupun telur ikan terubuk yang dikenal sebagai jenis ikan dengan harga jual yang tinggi mulai mengalami kelangkaan. Sebaliknya jenis ikan lomek mengalami kenaikan tangkapan setiap bulannya. Dengan jumlah tangkapan ikan lomek yang cukup banyak menyebabkan harga ikan lomek dipasaran hanya mencapai Rp.7.000/kg.

Harga jual ikan yang relatif murah dipasaran menyebabkan nelayan berpendapatan rendah. Penghasilan nelayan sebagian besar berada dibawah Rp. 2.000.000/bulan sehingga nelayan mengalami kesulitan untuk memenuhi kebutuhan sehari-hari. Pendapatan yang rendah membuat nelayan mulai mengembangkan hasil pengolahan ikan. Pengolahan yang dilakukan masih dengan cara yang sederhana berbasis industri rumah (home industry) seperti keripik dan nugget yang berbahan dasar lomek. Pengolahan ikan dengan cara tradisional yang selama ini dilakukan ternyata tidak cukup untuk meningkatkan pendapatan nelayan. Hal tersebut disebabkan kurangnya ilmu pengetahuan dan teknologi mengenai tata cara pengolahan.

Pembinaan masyarakat dalam pengolahan hasil tangkapan ikan di Desa Pangkalan Jambi dilakukan dalam tiga kegiatan inti yakni:

\section{Pembentukan skill dan pemberdayaan individu}

Proses pembentukan skill dan pemberdayaan individu dimulai pada tahap sosialisasi. Sosialisasi pertama yang dilakukan berupa pemaparan materi mengenai pentingnya pengembangan potensi perikanan pengolahan hasil tangkap ikan, penguatan kelembagaan, serta adanya inovasi dalam bidang teknologi. Selanjutnya, dilakukan penyuluhan terhadap masyarakat mengenai bagaimana cara menggunakan teknologi tepat guna dalam proses produksi makanan, obat-obatan maupun kosmetik hasil olahan ikan. Setelah itu, pelatihan dilakukan dengan mendatangkan tenaga ahli di bidangnya (Syahza et al., 2018).

\section{Pembentukan kelompok/ pembangunan kelembagaan}

Pembentukan kelompok dilakukan sebagai wadah dalam mengelola hasil pengolahan ikan. Selain itu, dengan dibentuknya kelompok diharapkan dapat memperkuat kerjasama dan koordinasi sehingga proses pengelolaan lebih terstruktur dengan visi dan misi yang ditetapkan. Masyarakat nelayan berhasil membentuk kelompok kecil yang bertujuan agar kegiatan-kegiatan pengelolaan bisa terkoordinir dengan baik yang disebut dengan Kelompok Harapan Bersama.

Kelompok Harapan Bersama terdiri dari sub kelompok budidaya ikan yang dinamakan Kelompok Rezeki Bersama serta sub kelompok pengolahan produk ikan yang dinamakan Kelompok Jaya Bersama. Dalam kelompok Jaya Bersama telah dibentuk beberapa pokja diantaranya pokja produksi, pokja pemasaran, dan pokja sarana dan prasarana. Seluruh kesatuan kelompok ini berinisiasi untuk mengembangkan potensi perikanan di Desa Pangkalan Jambi dan turut serta dalam menjaga ekosistem mangrove.

Pembinaan yang dilakukan setelah kelompok terbentuk adalah peningkatan partisipasi masyarakat dan resolusi konflik. Peningkatan partisipasi masyarakat dilakukan dengan cara mengajak serta masyarakat dalam seluruh kegiatan pembinaan, mulai dari budidaya ikan hingga pengembangan hasil pengolahan. Pengetahuan mengenai tata cara dan teknologi tidak hanya diberikan kepada kelompok melainkan juga pada masyarakat. Iptek diperlukan dalam proses pengolahan, teknologi dapat membantu proses produksi hingga pemasaran. Hasil pengolahan ikan tidak lagi hanya dipasarkan secara tradisional melainkan dikemas lebih menarik serta proses pemasaran yang dilakukan terintegrasi dengan berbagai pihak hingga pemasaran secara online. Penguatan Iptek secara tidak langsung dapat membantu mensejahterakan perekonomian masyarakat.

Selain peningkatan partisipasi masyarakat juga dilakukan resolusi konflik. Dengan pembentukan kelompok, diharapkan dapat mengurai berbagai permasalahan yang sudah terjadi sebelumnya seperti masalah abrasi, penebangan kayu mangrove secara illegal hingga pada konflik kepentingan. Selain itu, pembentukan kelompok juga diharapkan dapat menyelesaikan permasalahan kemiskinan yang dialami oleh nelayan. Permasalahan yang urgent dialami oleh nelayan adalah jenis tangakapan ikan lomek yang banyak namun memiliki harga jual yang cukup rendah sehingga jika tidak diolah maka akan memberikan kerugian yang cukup besar pada nelayan. Dalam hal ini kelompok akan menjadi wadah untuk berbagi informasi dan pengetahuan terutama mengenai pengetahuan tentang pengolahan hasil tangkap ikan.

\section{Bantuan Manajemen}

Pada kegiatan pengabdian yang telah dilaksanakan, bantuan manajemen yang diberikan pada kelompok adalah dalam bentuk bantuan keuangan, dengan membuat laporan keuangan kelompok. Sedangkan bantuan 
pemasaran dilakukan dengan bantuan promosi dan kerjasama dengan berbagai pihak sebagai supplier atau pemasok sehingga pemasaran tidak lagi hanya dilakukan secara tradisional.

Selama ini nelayan hanya mampu memasarkan hasil pengolahan ikan secara konvensional tanpa adanya pengolahan berbasis teknologi. Kelompok nelayan memiliki potensi untuk membuat hasil olahan makanan dari hasil tangkap ikan namun memiliki kendala diantaranya kendala untuk menaikkan minat masyarakat terhadap produk hasil olahan, pengemasan yang lebih modern, pembukuan, proses pemasaran dan promosi. Setelah dilakukan pengabdian, ada tiga program yang dilakukan diantaranya pembentukan skill individu, pembentukan kelompok serta bantuan manajemen. Kelompok Mangrove Harapan Bersama dibentuk sebagai wadah untuk mengelola hasil tangkap ikan. Ketiga program kegiatan ini diharapkan dapat membantu memecahkan persoalan yang dihadapi oleh kelompok nelayan hingga dapat meningkatkan kesejahteraan nelayan.

\section{KESIMPULAN}

Pengembangan potensi daerah perlu dilakukan agar dapat meningkatkan perekonomian dan mensejahterakan masyarakat Desa Pangkalan Jambi merupakan salah satu desa dengan potensi perikanan dan wisata bahari yang cukup mumpuni. Hasil tangkap ikan di Desa Pangkalan Jambi terdiri dari jenis ikan yakni ikan Terubuk, ikan Pias, ikan Tenggiri, ikan Biang dan ikan Lomek. Hasil rekapitulasi tangkapan setiap bulan menunjukkan bahwa jumlah ikan terubuk, pias, tenggiri dan biang berkurang setiap bulannya, sedangkan hasil tangkap ikan lomek selalu meningkat. Ikan Lomek merupakan jenis ikan bertekstur kenyal yang juga menjadi ciri khas masyarakat pesisir. Ikan lomek sangat mudah didapat, akan tetapi permintaan masyarakat terhadap jenis ikan ini tidak meningkat. Hal ini menyebabkan terjadinya kerugian yang dialami nelayan karena harga jual ikan lomek hanya mencapai Rp. $7.000 / \mathrm{kg}$.

Untuk memanfaatkan potensi ikan Lomek yang cukup banyak maka pembinaan perlu dilakukan kepada masyarakat terutama nelayan. Pembinaan dilakukan untuk mengolah hasil tangkap ikan Lomek menjadi makanan olahan yang memiliki nilai ekonomi yang tinggi. Sebagai wujud pembinaan, maka dibentuk kelompok yang dinamakan dengan Kelompok Harapan Bersama. Kelompok ini menjadi wadah untuk mengembangkan potensi hasil olahan ikan terutama ikan Lomek. Makanan hasil olahan diharapkan dapat membantu mensejahterakan para nelayan.

Setelah dilakukan pembinaan dengan tiga program inti yakni pembentukan skill dan pemberdayaan individu, pembentukan kelompok dan bantuan manajemen akan menciptakan sumberdaya manusia yang berkualitas. Nelayan menjadi lebih mandiri dan memiliki wawasan mengenai pemanfaatan ikan Lomek dengan bantuan teknologi. Hasil tangkap ikan dan hasil olahan ikan tidak lagi dipasarkan secara konvensional melainkan sudah terintegrasi dengan berbagai pihak sehingga proses pemasaran menjadi lebih mudah.

\section{UCAPAN TERIMA KASIH}

Pengabdian yang dilakukan tidak terlepas dari kerjasama dengan berbagai pihak, oleh karena itu, kami mengucapkan terimakasih kepada:

1. Prof. Dr. Almasdi Syahza, SE, MP. Selaku Ketua LPPM Universitas Riau.

2. Pemerintah Desa Pangkalan Jambi

3. Ketua dan Anggota Kelompok Anggota Nelayan Mangrove Harapan Bersama Pangkalan Jambi

\section{DAFTAR PUSTAKA}

Bagong, S. 2001. Kemiskinan dan Pemberdayaan Masyarakat Miskin. Kebudayaan dan politik 14(4): 25-42

Buchanan, R. A. 2006. Sejarah Teknologi (History of Technology), terj. Saut Pasaribu. Yogyakarta: Pall Mall.

Irianto, S. 2008. Nelayan Di Mata Kita Sebuah Perspektif Berpikir Sistem. Pekanbaru: CV. Sukabina.

Kamal, E. 2013. Otonomi Daerah Dan Pemberdayaan Nelayan. Pusitkom: Universitas Bung Hatta.

Kusnadi. 2006. Filosofi Pemberdayaan Pesisir. Bandung: Humaniora.

Kusnadi. 2007. Strategi Hidup Masyarakat Nelayan. Yogyakarta : LkiS.

Kusumastanto, T., \& Satria A. 2011. Strategi Pembangunan Desa Pesisir Mandiri. Menuju Desa 2030. Bogor: Crestpent Press. 
Syahza, A., D. Bakce, \& B. Asmit. 2018. Increasing the awareness of palm oil plantation replanting through farmers training. Riau Journal of Empowerment 1(1): 1-9. https://doi.org/10.31258/raje.1.1.1

Soemarwoto, O. 2001. Ekologi, Lingkungan Hidup, dan Pembangunan. Jakarta: Penerbit Djambatan.

Suharto, E. 2009. Membangun Masyarakat Memberdayakan Rakyat. Bandung: PT. Refika Aditama.

Totok \& Poerwoko. 2012. Pemberdayaan Masyarakat dalam Prespektif Kebijakan Publik. Bandung: Alfabeta.

Tuwo, H. A. 2011. Pengelolaan Ekowisata Pesisir dan Laut. Surabaya: Brilian Internasional. 